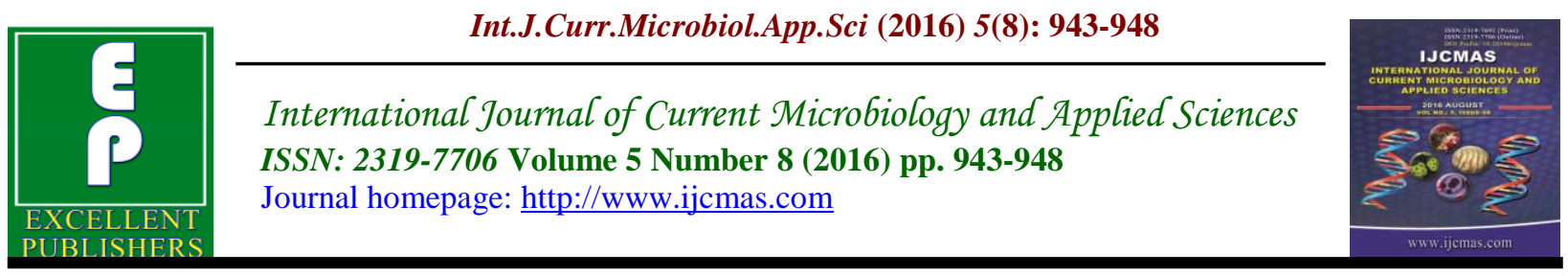

Original Research Article

http://dx.doi.org/10.20546/ijcmas.2016.508.106

\title{
Phytosterols Content in Different Bamboo Species of Manipur, India
}

\author{
Malemnganba Ingudam and Kananbala Sarangthem* \\ Plant Physiology Research Laboratory, Department of Life Sciences, \\ Manipur University, Canchipur, Imphal-795003, India \\ *Corresponding author
}

Keywords

Bamboo

shoots/

Phytosterols/

Manipur.

Article Info

Accepted:

28 August 2016

Available Online:

10 September 2016

\section{A B S T R A C T}

Bamboo shoots have a long history of being used as a source of both food and medicine. The use of bamboo shoots as a food and delicacy has been among the people of Manipur since time immemorial. Bamboo shoots are regarded as potential sources of sterols. In the present investigation some twelve bamboo species grown in Manipur were assessed for their phytosterols content and it was found that the phytosterols level varied in bamboo shoot samples of different species- ranging from 293.8 to $40.5 \mathrm{mg} / 100 \mathrm{~g}$ dry wt. Maximum content were found in the top apex portion of the bamboo shoots which were soft and tender but not used for consumption. The outer culm sheaths (covering the soft portion of the shoot) which are discarded also showed a significant amount of phytosterols ranging from 119.7 to $35.5 \mathrm{mg} / 100 \mathrm{~g}$ dry wt. The bamboo shoots show a gradual decrease in the total phytosterol content from top apex portion to base tissues of the bamboo shoots and lowest in the culm sheath. Lieberman-Burchard reaction was the basis for spectrocolometric estimation of total phytosterols.

\section{Introduction}

Phytosterols, which are the precursors of many pharmaceutically active steroids, are found in many plants (Martin, 1997; Jain et al., 1980). As of now 200 types of sterols exist in nature (Lagarda et al., 2006). ). In the recent advancement, there is considerable interest in phytosterols as dietary supplements as they are are shown to inhibit the absorption of cholesterol in the small intestine and also effectively lowers the cholesterol level (Ostlund et al., 2003). There are also reports that phytosterol seems to have a positive impact on cardiovascular diseases (Patel and Thompson, 2006; Weingartner et al., 2009).
Bamboo shoots are used by the people of south-east Asia as a food in different types of delicacies and also considered as a medicinal food (Bao, 2006; Baiyi et al, 2009). The emerging fresh young bamboo shoots which are used in numerous Asian dishes are available in markets in various sliced forms, fresh, fermented and canned version (Tai, 1985; Fu et al, 1987; Midmore, 1998) At present over two million tons of edible bamboo shoots are consumed in the world in each year (Yang et al., 2008). In Manipur, a state located in the north eastern part of India, the fresh succulent bamboo 
shoots slices and the fermented shoot slices done in large scale are highly prized vegetable food items. More than 700,000 culms are extracted every year in Manipur (Statistical bulletin of Manipur forest, Govt. of Manipur, 1999-2000). Young delicate bamboo shoots are of favourite because of its high fiber content and its delicacy (Fuchigami, 1990). They are rich in minerals, have adequate amount of glucose, low in fat and is brittle, tender, delicious and nutritive (Yamaguchi and Kusama, 1976; Yamaguchi, 1983; Park and John, 2009). Bamboo also contains many secondary metabolites which can be used as precursors of many pharmaceutical industries (Sarangthem and Singh, 2003).

Bamboo shoot contain a number of phytosterol (Srivastava,1990; Sarangthem and Srivastava ,1997 ; 1998; Sarangthem and Singh,2002; Baiyi et al, 2009). But the available literatures are from a limited number of bamboo species. Furthermore, comprehensive phytosterol content of various bamboo shoots of different species of bamboo is not available. Hence,in this paper, the phytosterols content in bamboo shoots of twelve species (Dendrocalamus brandisii Kurz, D. strictus D. giganteus Munro, D. flagellifer Munro D.hamiltonii Nees \& Arn.ex Munro, D. sericeus Munro De Bambusa tulda Roxb, B. balcooa Roxb. B. nutans Wall, B. kingiana Gamble, B. Khasiana Munro and Cephalostachyum pergracile Munro) were assessed for their phytosterols content in order to facilitate recommendations for utilization of the bamboo shoot as phytosterol resources.

\section{Materials and methods}

\section{Sample collection}

The emerging young fresh succulent bamboo shoots of Dendrocalamus brandisii
Kurz, D. strictus D. giganteus Munro, D. flagellifer Munro D.hamiltonii Nees \& Arn.ex Munro, D. sericeus Munro De Bambusa tulda Roxb, B. balcooa Roxb. B. nutans Wall, $B$. kingiana Gamble, $B$. khasiana Munro and Cephalostachyum pergracile Munro were collected during peak sprouting season (May-August) from different district of Manipur, India.

Collection of these bamboo shoots were made in the afternoon and processed the same day. The outermost scale portions of the fresh succulent bamboo shoots and the inner soft delicate shoots which are edible were taken out and kept separately for the experiment. For differentiation of the portion of the succulent bamboo shoots, the shoot are divided into 4 portions i.e. apex top, middle, base portion and the culm sheath covering the soft shoots.

The allocation of theses apex, middle and base portion is based purely on simple measurement. $1 / 4^{\text {th }}$ of the total length (from the base) of the shoot is considered as base. $1 / 3^{\text {rd }}$ of the total (after removing the base) is taken as middle portion and the remaining is taken as the apex.

The outer portions of the shoots are removed after peeling off the cover culm sheath and the remaining portions are divided into apex, middle and base portion. These portions separately are then sliced and oven air dried in an oven at $50-60^{\circ} \mathrm{C}$. The dried bamboo shoot slices were grinded using a grinder and then again dried to minimise the moisture content prior to the weighing for the estimation of phytosterol.

\section{Phytosterol estimation}

The total phytosterol was estimated using the Liberman Burchard reaction (Katayama, 1974). 
Table.1 Level of total phytosterols in fresh succulent shoot samples of different species of bamboo

\begin{tabular}{|c|c|c|}
\hline Name of the species & $\begin{array}{l}\text { Portion of the } \\
\text { bamboo shoots }\end{array}$ & $\begin{array}{l}\text { Concentration of total } \\
\text { phytosterols } \\
(\mathrm{mg} / 100 \mathrm{~g} \text { dry wt.) }\end{array}$ \\
\hline \multirow[t]{4}{*}{ Dendrocalamus brandisii } & Apex & $276.6 \pm 1.60$ \\
\hline & Middle & $234.0 \pm 0.31$ \\
\hline & Base & $185.8 \pm 7.6$ \\
\hline & Culm sheath & $61.8 \pm 1.6$ \\
\hline \multirow[t]{4}{*}{ Dendrocalamus strictus } & Apex & $212.4 \pm 12.1$ \\
\hline & Middle & $187.0 \pm 2.1$ \\
\hline & Base & $142.5 \pm 14.5$ \\
\hline & Culm sheath & $34.2 \pm 14.6$ \\
\hline \multirow[t]{4}{*}{ Dendrocalamus giganteus } & Apex & $198.7 \pm 1.3$ \\
\hline & Middle & $173.0 \pm 1.8$ \\
\hline & Base & $155.0 \pm 71.9$ \\
\hline & Culm sheath & $109.5 \pm 50.7$ \\
\hline \multirow[t]{4}{*}{ Dendrocalamus flagellifer } & Apex & $144.3 \pm 15.8$ \\
\hline & Middle & $109.5 \pm 2.6$ \\
\hline & Base & $88.0 \pm 9.4$ \\
\hline & Culm sheath & $69.3 \pm 3.0$ \\
\hline \multirow[t]{4}{*}{ Dendrocalamus hamiltonii. } & Apex & $293.8 \pm 16.1$ \\
\hline & Middle & $218.5 \pm 6.6$ \\
\hline & Base & $187.3 \pm 8.6$ \\
\hline & Culm sheath & $119.7 \pm 22.0$ \\
\hline \multirow[t]{4}{*}{ Dendrocalamus sericeus } & Apex & $266.0 \pm 14.5$ \\
\hline & Middle & $180.8 \pm 5.0$ \\
\hline & Base & $159.2 \pm 13.7$ \\
\hline & Culm sheath & $85.8 \pm 17.3$ \\
\hline \multirow[t]{4}{*}{ Bambusa tulda } & Apex & $190.0 \pm 15.7$ \\
\hline & Middle & $167.7 \pm 3.3$ \\
\hline & Base & $76.5 \pm 6.9$ \\
\hline & Culm sheath & $45.8 \pm 2.5$ \\
\hline \multirow[t]{2}{*}{ Bambusa balcooa. } & Apex & $190.0 \pm 10.5$ \\
\hline & Middle & $180 \pm 5.0$ \\
\hline
\end{tabular}




\begin{tabular}{|l|l|l|}
\hline \multirow{5}{*}{ Bambusa natans } & Base & $126.5 \pm 3.9$ \\
\cline { 2 - 3 } & Culm sheath & $60.0 \pm 1.5$ \\
\hline \multirow{5}{*}{ Bambusa kingiana } & Apex & $94.0 \pm 7.4$ \\
\hline \multirow{5}{*}{ Bambusa khasiana } & Middle & $57.5 \pm 4.4$ \\
\cline { 2 - 3 } & Base & $48.3 \pm 2.5$ \\
\cline { 2 - 3 } & Culm sheath & $35.5 \pm 1.0$ \\
\hline \multirow{5}{*}{ Cephalostachyum pergracile } & Apex & $222.0 \pm 10.8$ \\
\hline & Middle & $127.1 \pm 12.0$ \\
\cline { 2 - 3 } & Base & $101.8 \pm 8.0$ \\
\cline { 2 - 3 } & Culm sheath & $40.5 \pm 8.5$ \\
\hline & Apex & $289.0 \pm 5.8$ \\
\hline & Middle & $240.3 \pm 12.1$ \\
\cline { 2 - 3 } & Base & $199.0 \pm 3.5$ \\
\cline { 2 - 3 } & Culm sheath & $153.5 \pm 2.6$ \\
\hline & Apex & $215.0 \pm 31.8$ \\
\hline & Middle & $193.1 \pm 11.2$ \\
\cline { 2 - 3 } & Base & $132.0 \pm 26.5$ \\
\cline { 2 - 3 } & Culm sheath & $67.7 \pm 4.0$ \\
\hline
\end{tabular}

1 gram of the dried and powdered and sieved at 100mesh were used for extraction with $10 \mathrm{ml}$ of the solvent (ethanol: acetone in the ratio of 1:1). The mixture is then centrifuged at $2000 \mathrm{rpm}$ for $10 \mathrm{~min}$ and then $2 \mathrm{ml}$ of the supernatant is taken and allowed to get dried of the solvents in an air dried oven at $80^{\circ} \mathrm{C}$ and then $2 \mathrm{ml}$ of chloroform is added and then allowed to dissolve properly. This $2 \mathrm{ml}$ of the mixture is used for the estimation of total phytosterol in the sample. Liberman Burchard reagent is prepared by the addition of $\mathrm{H}_{2} \mathrm{SO}_{4}$ to Acetic Anhydride in the ratio of 1:30. The reagent is prepared for each test freshly and used within 10 minute. For the reaction to proceed, to the 2 $\mathrm{ml}$ of the mixture, $3 \mathrm{ml}$ of the reagent is added. The reaction mixture will give a characteristic green colour and the O.D is taken within 5-10 minute in a Spectrophotometer (Spectroquant) and recorded. The process is done in triplicate for each sample and the mean total phytosterol is taken. The amount of phytosterol present in the sample was calculated from the standard curve prepared by using cholesterol as the standard.

\section{Results and Discussion}

The bamboo shoots of the different bamboo species shows a varying content of phytosterols . The higest concentration was obtained with Dendrocalamus hamiltonii apex portion of the bamboo shoot with 293.8 $\mathrm{mg} / 100 \mathrm{~g}$ dry wt. , the middle portion with $218.5 \mathrm{mg} / 100 \mathrm{~g}$ dry wt. ,base portion with $187.3 \mathrm{mg} / 100 \mathrm{~g}$ dry wt. and $119.7 \mathrm{mg} / 100 \mathrm{~g}$ dry wt. in the culm sheath. The lowest content in phytosterols were observed with that of Bambusa nutans having 94.0 $\mathrm{mg} / 100 \mathrm{~g}$ dry wt. in the apex portion , 57.5 $\mathrm{mg} / 100 \mathrm{~g}$ dry wt. in the middle portion , base $48.3 \mathrm{mg} / 100 \mathrm{~g}$ dry wt. and 35.5 $\mathrm{mg} / 100 \mathrm{~g}$ dry wt. as shown in table 1 . The 
concentration of total phytosterol in the parts of the bamboo shoots show a general trend with the top apex portion having the highest concentration and keeps on decreasing towards the base portion. This shows that the apex young meristematic tissue can be used for phytosterols extraction. The culm sheath cover of the shoot also show the presence of phytosterol but the content was much lower than the base of the bamboo shoot.

The current findings showed that bamboo shoots of Dendrocalamus hamiltonii has the highest content of phytosterol. These bamboo species can be further propagated and the use of its fresh bamboo as a food in the region can help in curbing the problem of high cholesterol in body (Patel and Thompson, 2006; Weingartner et al., 2009). Bambusa khasiana which propagate very fast also shows high level of phytosterol. These phytosterol act as nutraceuticals and are precursors of many pharmaceutically active steroidal drugs (Ostlund et al.,2003 ; Sarangthem and Singh, 2003). Hence it can be concluded that bamboo shoots may be promoted as health enhancing food due to its rich phytosterol components which can be of high value to the pharma industries eyeing on potent nutraceuticals .

\section{Acknowledgments}

The Authors are thankful to the Dept. of Biotechnology (DBT), Govt. of India (.BT/475/ NE/ TBP / 2013), for providing financial support to carry out the research work.

\section{References}

Baiyi, L. , Yipin Ren, Ying, Zhang, Jinyan Gong .2009. Effects of genetic variability, parts and seasons on the sterol content and composition in bamboo shoots. Food Chemistry. 112: 1016-1021.

Bao, J. 2006. The nutrition and bio-active function of bamboo shoots. Food and Nutrition in China.4: 2-3.

$\mathrm{Fu}$,M.Y., Ma, N.X., Qui ,F.G. 1987. Bamboo production and scientific research in Thailand. Chinese Journal of Bamboo Research .6(1): 54-61.

Fuchigami, M. 1990. Differences between bamboo shoots and vegetables in thermal disintegration of tissues and polysaccharides fractionated by successive extraction. J Food Sci.55:739-45.

Jain, S. C, Kamal, R. and Rathore A.K. 1980. A note on phytosterols in same species. Indian Drugs. 17(5):145.

Katayama ,M., Holl, C.T., Chen, NC., Hirota, T , Kiribuchi, J. and Sumahashi, S . 1974. A method for fractional determination of soybean in four class by florisil column chromatography. Agri. Biol. Chem . 38: 1661 .

Lagarda, M. J., Garcia-Llatas, G., \& Farre, R. 2006. Analysis of sterol in foods. Journal

of Pharmaceutical and Biomedical Analysis. 41(5): 1486-1496.

Martin, C. K. A., 1997.Advances in Applied Microbiology (ed. Perlman, D.), Academic Press, New York. vol. 22, pp. 29-64.

Midmore, D.1998. Culinary bamboo shoots. In:The New Rural Industries. Hyde, KW, editor. Rural Industries Research and Development Corporation..p.188-196

Ostlund, R.E, Racette, SB., Stenson W.F. 2003 . Inhibition of Cholesterol Absorption by Phytosterol-Replete Wheat Germ Compared With Phytosterol-Depleted Wheat Germ.Am. J. Clin. Nutr. 77 (6): 1385-1589.

Park ,E,., Jhon, D .2009. Effects of bamboo 
shoot consumption on lipid profiles and bowel function in healthy young women. Nutrition. 25(7-8): 723-728.

Patel , M.D. and Thompson, P.D. 2006. Phytosterols and Vascular Disease. Atherosclerosis. 186 (1):12-19.

Sarangthem, K. and Srivastava, R.C. 1997. Enrichment of phytosterols level in fermenting sample of succulent shoots of Dendrocalamus species grown in Manipur. Proc.Nat. Acad. Sci. letters. 20(5\&6): 64-67.

Sarangthem, K., Singh, L. J. and Srivastava, R. C., 1998. Isolation of stigmasterol from fermented succulent bamboo shoots and its biotransformation into ADD using Arthrobacter globiformis. Indian J. Plant Physiol. 3: 249-252.

Sarangthem ,K., Singh, T.N. 2002. Biosynthesis of succulent bamboo shoots of Bambusa balcooa into phytosterols and its biotransformation into ADD Acta Botanica Sinica .45 (1): 114-117

Sarangthem, K., Singh, T.N. 2003. Microbial bioconversion of metabolites from fermented succulent bamboo shoots into phytosterols. Current Science.84(12): 1544-1547.

Srivastava, R.C. 1990. Bamboo: new raw materials for phytosterols. Current Science. 59: 1333-1334.

Tai, K.Y. 1985 .The management and utilization of shoot producing bamboos in Taiwan, J . Chinese forestry 18 (2): $1-46$

Weingärtner O. et al. 2009. Controversial Role of Plant Sterol Esters in the Management of

Hypercholesterolaemia. European Heart Journal . 30: 404-409

Yang ,Q., Duan ,Z, Wang ,Z., He K, Sun, Q., Peng, Z. 2008. Bamboo resources, utilization and ex-situ conservation in Xishuangbanna, South-eastern China.Journal of Forest Resource 19(1): 79-83.

Yamaguchi, M., Kusama, M. 1976. The nutritive compounds of several dried bamboo shoots. Yokyo Kasai, Kentyu. 16:59-61.

\section{How to cite this article:}

Malemnganba Ingudam and Kananbala Sarangthem. 2016. Phytosterols Content in Different Bamboo Species of Manipur, India. Int.J.Curr.Microbiol.App.Sci. 5(7): 943-948. doi: http://dx.doi.org/10.20546/ijcmas.2016.507.106 